Strategic Firm Commitments and Rewards for Customer Relationship Management in Online Retailing

Author(s): Raji Srinivasan and Christine Moorman

Source: Journal of Marketing, Vol. 69, No. 4 (Oct., 2005), pp. 193-200

Published by: American Marketing Association

Stable URL: http://www.jstor.org/stable/30166561

Accessed: $23 / 09 / 2013$ 17:26

Your use of the JSTOR archive indicates your acceptance of the Terms \& Conditions of Use, available at

http://www.jstor.org/page/info/about/policies/terms.jsp

JSTOR is a not-for-profit service that helps scholars, researchers, and students discover, use, and build upon a wide range of content in a trusted digital archive. We use information technology and tools to increase productivity and facilitate new forms of scholarship. For more information about JSTOR, please contact support@jstor.org. 


\section{Strategic Firm Commitments and Rewards for Customer Relationship Management in Online Retailing}

Academic studies offer a generally positive portrait of the effect of customer relationship management (CRM) on firm performance, but practitioners question its value. The authors argue that a firm's strategic commitments may be an overlooked organizational factor that influences the rewards for a firm's investments in CRM. Using the context of online retailing, the authors consider the effects of two key strategic commitments of online retailers on the performance effect of CRM: their bricks-and-mortar experience and their online entry timing. They test the proposed model with a multimethod approach that uses manager ratings of firm CRM and strategic commitments and third-party customers' ratings of satisfaction from 106 online retailers. The findings indicate that firms with moderate bricks-and-mortar experience are better able to leverage CRM for superior customer satisfaction outcomes than firms with either low or high bricks-and-mortar experience. Likewise, firms with moderate online experience are better able to leverage CRM into superior customer satisfaction outcomes than firms with either low or high online experience. These findings help resolve disparate results about the value of CRM, and they establish the importance of examining CRM within the strategic context of the firm.

\section{$\mathbf{T}$} he study and practice of customer relationship management (CRM) has experienced explosive growth over the past decade. Extant research provides two sets of insights into the relationship between a firm's CRM investments and its performance. The first set focuses on CRM as expenses. Gupta, Lehmann, and Stuart (2004) find that customer acquisition and retention expenses have a significant, positive effect on firm value. Other studies report a positive relationship between a firm's CRM technology investments and CRM performance (Jayachandran et al. 2005; Mithas, Krishnan, and Fornell 2005). The second set of studies envisions CRM as a firm capability and, again, reports its positive effects on both CRM and business performance (Day and Van den Bulte 2002; Reinartz, Krafft, and Hoyer 2004).

However, these findings are in contrast to increasing practitioner skepticism of CRM expenditures. As Day and Van den Bulte (2002) note, practitioners report that the majority of CRM initiatives fail to meet expectations (Dignan 2002). Indeed, CRM has been decried as one of the biggest blunders of the early twenty-first century (Infoworld 2001); there is evidence that most CRM initiatives do not deliver the anticipated return on investment (Gartner Group 2003).

Raji Srinivasan is Assistant Professor of Marketing, Red McCombs School of Business, University of Texas at Austin (e-mail: raji.srinivasan@ mccombs.utexas.edu). Christine Moorman is T. Austin Finch Jr. Professor of Business Administration, Fuqua School of Business, Duke University (e-mail: moorman@duke.edu). The authors thank the Marketing Science Institute for its financial assistance; Dave Reibstein for his assistance in securing the data; BizRate.com for providing data; the consulting editors Bill Boulding and Rick Staelin; and commentators Rajesh Chandy, Marnik Dekimpe, Abhijit Guha, Jennifer Francis, Wayne Hoyer, Julie Irwin, Mitch Lovett, John Lynch, Vijay Mahajan, Arvind Rangaswamy, Roland Rust, Raj Srivastava, and Rajan Varadarajan for helpful comments on previous versions of the article.
This divergence in the effectiveness of CRM across theory and practice is both troubling and intriguing. It is troubling because though CRM as a way to manage customers is here to stay, increasing skepticism among practitioners signals that CRM will face intense scrutiny and accountability. From a theoretical perspective, the divergence is intriguing because it implies that the observed variability in CRM performance may be explained by moderating factors.

Considering possible explanations for the observed variability, researchers have examined (1) CRM data-related techniques (e.g., Ansari and Mela 2003), (2) marketing strategies for customer profitability (e.g., Reinartz and Kumar 2000, 2003; Rust, Lemon, and Zeithaml 2004; Rust and Verhoef, 2005; Venkatesan and Kumar 2004), (3) the balance between customer acquisition and retention efforts (e.g., Reinartz, Thomas, and Kumar 2005), and (4) effective CRM implementation (Day and Van den Bulte 2002; Reinartz, Krafft, and Hoyer 2004). Although impressive in scope, extant research offers few insights on the strategic choices that are associated with the effective deployment of CRM. This is remiss because strategic conduct influences the effect of customer satisfaction on firm value (Anderson, Fornell, and Mazvancheryl 2004).

We address this gap in the literature. Specifically, we ask whether the effect of a firm's CRM on CRM performance, as measured by customer satisfaction ratings, is influenced by its prior strategic commitments. Strategic commitments can involve any long-term firm decision, such as the choice to enter specific markets or invest in products, brands, channels, or partnerships. Using the empirical context of the emerging online retailing market, we investigate whether CRM performance is weakened or strengthened by two relevant prior strategic commitments of the retailer: (1) bricks-and-mortar or offline experience and (2) online entry timing. We test our predictions using manager ratings of 
CRM and strategic commitments and customer ratings of satisfaction in 106 online retailers.

\section{Predictions}

\section{CRM and Firm Bricks-and-Mortar Experience}

Bricks-and-mortar experience refers to the firm's level of offline experience before its online entry. Bricks-andmortar experience is a form of strategic commitment that reflects the retailer's incumbency in offline retailing. Traditionally, studies of incumbency have focused on an incumbent's ability to innovate an emerging technology (e.g., Chandy and Tellis 2000). In this study, we examine the effects of incumbency on the effectiveness of a firm's CRM investments in an emerging market. Our review of the literature suggests that there are both customer and firm explanations for this question.

Customer factors. Several customer-based factors imply that a firm's bricks-and-mortar experience may strengthen the effect of its CRM on performance. First, bricks-andmortar retailers have existing supply chain infrastructures, which should improve fulfillment efficiency, a key success factor in online environments. Second, bricks-and-mortar online retailers have access to extensive customer information from their offline operations, which may improve their ability to deploy CRM effectively to serve online customers. Third, bricks-and-mortar firms' offline brand and relationship equities can be leveraged in their online operations (Geyskens, Gielens, and Dekimpe 2002). These market-based assets (Srivastava, Shervani, and Fahey 1998) may help the firm establish strong online customer relationships. For example, bricks-and-mortar operations may serve as a "source of advertising to pre-sell merchandise" (Alba et al. 1997 , p. 48 ).

Finally, bricks-and-mortar retailers enable online customers the option to experience products before they purchase them, which reduces customers' uncertainty and helps them identify products that closely match their preferences, thus increasing their satisfaction (Alba et al. 1997). Customers may also prefer returning products purchased from online retailers to the offline store, saving shipping costs. Thus, the bricks-and-mortar experience of retailers can complement their online operations and increase the returns on their online CRM investments.

Firm factors. Although there are positive effects involving customer-based factors, several features of bricks-andmortar online retailers suggest the opposite. First, incumbents with a long history of offline retailing may be concerned about cannibalizing their bricks-and-mortar operations (Alba et al. 1997; Lynch and Ariely 2000). As Ghosh (1998, p. 127) notes, "Established businesses that ... have carefully built brands and physical distribution relationships risk damaging all they have created when they pursue commerce in cyberspace." As a result, bricks-andmortar firms may be less aggressive in their online CRM efforts. As Kanter (2001, p. 92) notes, "Ask big companies about their goals for the Web, for example, and they are likely to reply, 'Cautious testing.' Ask dot-coms and they declare, 'Total world domination!'”
Second, bricks-and-mortar experience of online retailers may be viewed as an organizational routine involving tacit knowledge (Nelson and Winter 1982). Transfers of such tacit knowledge are often characterized by stickiness and misapplication (Szulanski 1996). Thus, bricks-and-mortar retailers may inappropriately transfer knowledge from their offline operations to their online operations, negatively affecting online performance. Indeed, because offline and online business models are distinct, bricks-and-mortar retailers may need to unlearn what led to their offline success in the design of their online CRM systems (Kanter 2001).

Prediction. Integrating the evidence, we expect that moderate levels of bricks-and-mortar experience should produce the highest performance returns on a firm's CRM investments. Moderate bricks-and-mortar experience provides access to key market-based assets without concerns about cannibalization or the well-entrenched routines that may create incumbency inertia. Conversely, low bricks-andmortar experience offers only freedom from the inhibiting aspects of incumbency, and high bricks-and-mortar experience offers only access to customer relationships and knowledge. Thus:

$\mathrm{H}_{1}$ : The positive effect of CRM on performance is stronger for firms with moderate bricks-and-mortar experience than for firms with low or high levels of bricks-and-mortar experience.

\section{CRM and Firm Online Experience}

A retailer's decision to enter online markets represents an important strategic commitment. We use the term "firm online experience" to capture the firm's entry-timing strategy, and we define it as the firm's online experience relative to the first entrant in the industry. Several aspects of online retailing, especially in its early years, suggest that the returns on a firm's CRM investments are influenced by its entry timing. In line with $\mathrm{H}_{1}$, we offer both customer and firm explanations to derive our prediction.

Customer factors. Some aspects of online customers imply that a firm's online experience may influence its performance rewards for CRM investments. Customers gain efficiencies when switching to online (from offline), which may increase switching costs, satisfaction, and loyalty (Johnson, Bellman, and Lohse 2003; Zauberman 2003). Thus, early entrants may be able to extract the greatest performance rewards from their CRM investments. However, this argument overlooks a key feature of emerging markets; namely, early markets are different from the mass market in terms of customers' willingness to take risks (e.g., Rogers 1995). In addition, customers in early markets have weaker expectations given the nascent status of these markets (Boulding et al. 1993). Thus, early entrants that establish customer relationships with early adopters may be disadvantaged when targeting later adopters (Degeratu, Rangaswamy, and $\mathrm{Wu} 2000$ ). This is problematic because most customers enter the market during the middle and later stages of market evolution. Thus, firms may expect the strongest response to their CRM investments when they enter in the middle stages of market evolution, not in the earlier or later stages. 
Firm factors. Several aspects related to a firm's online experience suggest that there are advantages for later entrants to achieve higher performance from their CRM investments. First, online retailing is a new technology that is characterized by firm (e.g., changes in Web design) and customer (e.g., learning how to use the online interface) experimentation. Indeed, online retailers continually reengineer their strategies to meet the evolving needs of online customers (Wind and Mahajan 2002). Thus, later entrants may have an advantage over early entrants in configuring cost-effective CRM systems.

Second, emerging markets, such as online retailing, are characterized by technological turbulence. For example, the performance-price ratios of online CRM technology increased dramatically over time, such that later entrants implemented more cost-effective CRM investments than early entrants. As such, early online entrants with large investments in vintage CRM technology incur considerable upgrade costs to remain competitive (The Gartner Group 2003). In turn, early entrants' unwillingness to incur these costs creates gateways for later entrants (Golder and Tellis 1993).

Prediction. Integrating these arguments, we expect that firms with moderate online experience receive the greatest rewards for CRM investments. We argue that when online entry moves from moderate to early, there may be reductions in the effectiveness of CRM investments due to differences in online customer cohorts or to evolving information technologies that are costly to upgrade. Conversely, late entrants may fail to achieve strong performance because of customer loyalty to early entrants. Thus:

$\mathrm{H}_{2}$ : The positive effect of CRM on performance is stronger for firms with moderate online experience than for firms with low (late entrants) or high (early entrants) online experience.

\section{Method}

\section{Data}

We test the predictions using a multimethod approach in a sample of online retailers. The population consisted of online retailers that were enrolled in BizRate.com's rating service in the summer of 2001. BizRate.com inserts a popup HTML that invites an online retailer's customers to participate in a survey that rates their satisfaction with a retailer after completion of a purchase from the retailer. After order fulfillment by the retailer, BizRate.com sends a second e-mail survey to these customers to obtain customer satisfaction ratings.

BizRate.com sent a Web link by e-mail to the senior managers of firms enrolled in its service on May 1, 2001, inviting them to participate in our study. In return, firms were promised information about how their firm compared with other firms on key variables. A total of 187 of the 978 online firms responded to the survey, for a response rate of $19 \%$. Key informants, who averaged 46 months' tenure, reported high levels of confidence $(5.80 / 7.00)$ in the information they provided. The average firm size in the sample was 202 employees (standard deviation [s.d.] = 747), and the average age of online operations was 41 months (s.d. = 24); in addition, most retailers had offline experience $(63 \%)$.
To investigate selection bias, we randomly selected 100 nonrespondent firms and compared them with the respondent firms on variables obtainable from public sources: (1) publicly held versus privately held and (2) bricks-andmortar operations or not. We found no significant differences between respondent and nonrespondent firms. ${ }^{1}$ Of the 187 retailers that responded to our survey, BizRate.com had customer satisfaction data for 106 , which formed the sample for this study. ${ }^{2}$ We found no significant differences between the 106 retailers with customer-ratings data and the 81 retailers without customer-ratings data. ${ }^{3}$

\section{Customer Satisfaction Measure}

We focus on customer satisfaction as the performance metric associated with CRM success. In addition to its inherent value as a key CRM performance metric, satisfaction positively affects other performance metrics, including retention, share-of-wallet, and even shareholder value (Anderson, Fornell, and Mazvancheryl 2004).

Customer satisfaction has been defined either as transaction specific or as cumulative (Boulding et al. 1993). Transaction-specific customer satisfaction is the customer's postchoice evaluative judgment of a specific purchase occasion (Boulding, Kalra, and Staelin 1999). In contrast, cumulative customer satisfaction is the customer's overall evaluation of the accumulated customer experiences with the firm (Fornell 1992). In this study, we focus on transactionspecific satisfaction. Given our emphasis on the performance of a retailer's online CRM investments, cumulative satisfaction is not appropriate, because it also includes customers' experiences with a retailer's bricks-and-mortar operations, when such operations are available.

Furthermore, because order fulfillment is a crucial element of CRM in online retailing (Reibstein 2002), we use satisfaction ratings that customers provided after order fulfillment. Specifically, BizRate.com asks, "How satisfied are you overall with this purchase experience at (merchant name) site?" on a scale that ranges from 1 ("not at all") to 10 ("highly") (see the Appendix). We averaged three months of a firm's postfulfillment customers' satisfaction ratings following our manager survey (i.e., June, July, and August 2001) to the firm level to obtain a firm-level measure of customer satisfaction performance $($ mean $=8.68$, s.d. $=.58 ; \alpha=.80)$.

\section{CRM Measures}

We use two measures of firm CRM. First, we use an eightitem measure that reflects the firm's CRM system invest-

'Tests find no differences in public versus private $\left(\chi^{2}{ }_{(1)}=.13\right.$, not significant) and presence versus absence of bricks-and-mortar operations $\left(\chi^{2}(1)=2.08\right.$, not significant) for respondent and nonrespondent firms.

${ }^{2}$ At the time, BizRate.com offered two plans. In the first plan (the 106 online retailers that responded to our survey), BizRate.com surveyed customers and provided firms with firmspecific customer data. In the second plan ( 81 firms), BizRate.com did not survey customers and offered these online retailers overall aggregate data instead.

${ }^{3}$ The $\mathrm{t}$-tests of difference between the 87 firms (with no customer data) and the 106 firms (with customer data) were not significant on size $(t=1.612$, not significant $), C R M$ system investments $(t=$ -.787 , not significant $)$, or CRM capability $(t=-.973$, not significant $)$. 
ments, which we obtained from a senior manager. Six items assess the firm's investments in CRM activities ( $1=$ "low investments," 4 = "moderate investments," and $7=$ "high investments"; see the Appendix). Two items assess the online retailer's CRM acquisition and retention expenses relative to the industry $(1=$ "worse than industry average," 4 = "on par," and 7 = "better than industry average"; see the Appendix). ${ }^{4}$ Together, these eight items form our measure of CRM system investments (mean $=5.04$, s.d. $=.93 ; \alpha=.77$ ).

Second, we complement the measure of the firm's CRM system investments with an assessment of its CRM capability. Reinartz, Krafft, and Hoyer (2004) and Day and Van den Bulte (2002) developed measures of a firm's CRM capability. Unfortunately, these measures were not available when our survey was launched. Fortunately, these new measures are theoretically founded in the firm's market orientation, an organizationwide system for acquiring, disseminating, and responding to customer information (Kohli and Jaworski 1990). This foundation reinforces the importance of market orientation to a firm's CRM capability. However, a firm's CRM capability extends beyond its market orientation, and our use of market orientation represents a weak test of the role of a firm's CRM capability.

Given length constraints imposed by BizRate.com, we used 14 items from Kohli, Jaworski, and Kumar's (1993) 20-item market orientation scale (see the Appendix; mean = 4.92 , s.d. $=.78 ; \alpha=.76) .{ }^{5}$ Notably, CRM system investments and CRM capability, as measured by market orientation, are only moderately correlated $(\rho=.32, p<.01)$.

\section{Strategic Commitment Measures}

Bricks-and-mortar experience. We constructed this measure from managers' reports of dates. The difference (in days) between "days since firm founding" and "days since firm Web entry," both measured from our survey date (May 1, 2001), is our measure of bricks-and-mortar experience (mean = 2161 days or 5.92 years, s.d. $=4432$ days or 12.14 years).

Online experience. We also constructed this measure from manager reports of the dates of their firm's online entry. Two coders assigned firms to one of eight industries (shoes and apparel, books and music, electronics and computers, health and medicine, flowers and gifts, home and kitchen furnishings, sporting equipment, and specialty occasion [e.g., bridal, birthday, baby]). Interjudge reliability was $88 \%$, and disagreements were resolved through discussion.

Using this industry classification, we calculated the number of days since entry for each firm from the date of

\footnotetext{
${ }^{4} \mathrm{~A}$ reviewer raised the concern that the two CRM acquisition and retention expense questions may have been answered on a per customer basis so that the "better than" anchor (rating 7) may have been viewed as "lower" (more efficient); thus, a higher rating (7) may actually reflect lower CRM system investments per customer. However, because we provide explicit instructions to the respondent to evaluate these items at the overall firm level, these two items form a reliable scale together with the remaining six items; separate analysis involving the six-item scale and the two-item scale produce similar results, so this concern does not seem problematic.

$5 \mathrm{We}$ also estimated the model with Homburg and Pflesser's (2000) measure of market-oriented organizational culture, and we obtain similar results.
}

the first entrant in the firm's industry. We computed the firm's online experience as the difference between the number of days since entry for the industry's first entrant and the number of days since the firm's online entry. To facilitate interpretation such that the first entrant into a category had maximum online experience and smaller numbers indicate less online experience, we subtracted the firm's online experience from May 1, 2001, our survey date (mean = 1180 days or 3.23 years, s.d. $=670$ days or 1.84 years).

\section{Control Variable}

Finally, we controlled for the well-known effect of consumer experience on customer satisfaction (Johnson, Bellman, and Lohse 2003). We measured the firm's customer online experience level by the average number of online purchases the firm's customers made in the product category in the previous six months (mean $=3.19$, s.d. $=1.12$ ).

\section{Results}

\section{Model Testing Approach}

To examine the moderating effect of a firm's strategic commitments on the effectiveness of its CRM, we used a threestep hierarchical linear regression model. Step 1 included the main effects of firm CRM, strategic commitments, and the control variable. Step 2 included the two-way interactions between CRM and its strategic commitments. Finally, Step 3 included the interactions between CRM and quadratic forms of the strategic commitment variables. Thus, our model is as follows:

$$
\begin{aligned}
\text { SAT }_{\mathrm{i}}=\text { Step 1: } & \beta_{0}+\beta_{1} \mathrm{CRM}_{-} \text {Invest }_{\mathrm{i}}+\beta_{2} \mathrm{CRM} \_ \text {Cap } \\
& +\beta_{3} \mathrm{BME}_{\mathrm{i}}+\beta_{4} \mathrm{OE}_{\mathrm{i}}+\beta_{5} \mathrm{Cust}_{-} \operatorname{Exp}_{\mathrm{i}}+\varepsilon_{1 \mathrm{i}} ; \\
\text { Step 2: } & \beta_{6}\left(\mathrm{BME}_{\mathrm{i}} \times \mathrm{CRM}_{-} \text {Invest }_{\mathrm{i}}\right) \\
& +\beta_{7}\left(\mathrm{BME}_{\mathrm{i}} \times \mathrm{CRM}_{-} \mathrm{Cap}_{\mathrm{i}}\right) \\
& +\beta_{8}\left(\mathrm{OE}_{\mathrm{i}} \times \mathrm{CRM} \text { Invest }_{\mathrm{i}}\right) \\
& +\beta_{9}\left(\mathrm{OE}_{\mathrm{i}} \times \mathrm{CRM}_{-} \mathrm{Cap}_{\mathrm{i}}\right)+\varepsilon_{2 \mathrm{i}} ; \\
\text { Step 3: } & \beta_{10} \mathrm{BME}_{\mathrm{i}}^{2}+\beta_{11} \mathrm{OE}_{1}^{2} \\
& +\beta_{12}\left(\mathrm{BME}_{\mathrm{i}}^{2} \times \mathrm{CRM}_{-} \text {Invest }_{\mathrm{i}}\right) \\
& +\beta_{13}\left(\mathrm{BME}_{\mathrm{i}}^{2} \times \mathrm{CRM}_{-} \text {Cap }_{\mathrm{i}}\right) \\
& +\beta_{14}\left(\mathrm{OE}_{\mathrm{i}}^{2} \times \mathrm{CRM}_{-} \text {Invest }_{\mathrm{i}}\right) \\
& +\beta_{15}\left(\mathrm{OE}_{\mathrm{i}}^{2} \times \mathrm{CRM}_{-} \text {Cap }_{\mathrm{i}}\right)+\varepsilon_{3 \mathrm{i}},
\end{aligned}
$$

where $S_{A T} T_{i}$ is customer satisfaction, CRM_Invest $t_{t}$ is CRM system investments, CRM_Cap ${ }_{i}$ is CRM capability, BME $_{i}$ is bricks-and-mortar experience, $\mathrm{OE}_{\mathrm{i}}$ is online experience, and Cust_Exp is customer online experience for firm i. We mean centered all explanatory variables before creating the interaction terms to avoid multicollinearity. To assess the potential threat from multicollinearity, we examined variance inflation factors and found them to be below harmful levels (Mason and Perreault 1991).

\section{Overall Model Results}

Step 1 (main effects) was significant $\left(\mathrm{F}_{(5,100)}=6.78, p<\right.$ $.01)$. Step 2, with the two-way interactions between CRM 
and the strategic commitments, was also significant $\left(\mathrm{F}_{(9,96)}=4.16, p<.01\right)$ as was the change in $\mathrm{F}$ associated with entry of this step (change in $\mathrm{F}_{(4,96)}=3.43, p<.01$ ). Finally, Step 3, with the interactions between CRM and quadratic forms of the strategic commitments, was also significant $\left(\mathrm{F}_{(15,90)}=3.85, p<.01\right)$ as was the change in $\mathrm{F}$ associated with entry of this step (change in $F_{(10,90)}=3.76$, $p<.01)$. Given these results, we interpret the full model results in Table 1.

The results indicate that the firm's CRM system investments $(\mathrm{b}=.30, p<.01)$ and CRM capability, in the form of market orientation $(b=.29, p<0.05)$, positively affect customer satisfaction. ${ }^{6}$ In addition, the control variable, customer online experience, negatively affects customer satisfaction $(\mathrm{b}=-.28, p<.01)$. We conjecture that increasing consumer experience may increase customers" "should" expectations, producing a negative effect (Boulding et al. 1993). We next examine tests of $\mathrm{H}_{1}$ and $\mathrm{H}_{2}$ pertaining to the moderating effects of bricks-and-mortar experience and online experience on the rewards for CRM.

\section{CRM and Firm Bricks-and-Mortar Experience $\left(H_{1}\right)$}

In $\mathrm{H}_{1}$, we predict an inverted U-shaped effect of a firm's bricks-and-mortar experience on CRM effectiveness. We first discuss the results with respect to a firm's CRM system investments, followed by its CRM capability.

CRM system investments. The first-order interaction term $\left(\mathrm{BME}_{\mathrm{i}} \times \mathrm{CRM} \_\right.$Invest $\left.\mathrm{i}_{\mathrm{i}}\right)$ is positive and significant $(\mathrm{b}=.20$, $p<.10)$, and the second-order interaction term $\left(\mathrm{BME}_{\mathrm{i}}^{2} \times\right.$ CRM_Invest $\left.\mathrm{i}_{\mathrm{i}}\right)$ is negative and significant $(\mathrm{b}=-.80, p<.01)$, in support of $\mathrm{H}_{1}$. To determine the nature of the moderating effect, we examine the returns on CRM system investments at different levels of bricks-and-mortar experience. To do so, we use the unstandardized parameter estimates from Equation 1 (not the standardized estimates we report in Table 1) that are pertinent to bricks-and-mortar experience and CRM system investments to calculate and plot the estimated coefficients of CRM system investments for different levels of bricks-and-mortar experience in Figure 1.7

As expected, the inverted $U$ shape in Figure 1 indicates that moderate bricks-and-mortar experience strengthens the effects of a firm's CRM system investments more than low and high levels of bricks-and-mortar experience. ${ }^{8}$ Approximately 12 years of bricks-and-mortar experience maximizes customer satisfaction returns on CRM system investments (.22). Additional analysis indicates that CRM returns drop

\footnotetext{
${ }^{6}$ Note that the regression coefficients for the first-order terms in mean-centered models are conditional effects at mean values of the other predictor variables and must be interpreted with caution (Irwin and McClelland 2001). As we subsequently show in Figure 1 and Figure 2, CRM system investments have a positive effect on performance, except at low online experience.

${ }^{7}$ Rearranging Equation 1, the parameter estimate for CRM_Invest $t_{i}$ is $\left(\hat{\beta}_{1}+\hat{\beta}_{6} \mathrm{BME}_{\mathrm{i}}+\hat{\beta}_{12} \mathrm{BME}_{\mathrm{i}}^{2}\right)$. However, Equation 1 is mean centered; thus, $\mathrm{BME}_{\mathrm{i}}$ is $\mathrm{BME}_{\mathrm{i} \text { (observed) }}-\mu_{(\mathrm{bme})}$. Thus, the effect of CRM system investments at $\mathrm{BME}_{\mathrm{i}(\mathrm{observed})}$ is $\left(\hat{\beta}_{1}+\right.$ $\left.\hat{\beta}_{6}\left[\mathrm{BME}_{\mathrm{i}(\text { observed })}-\mu_{(\mathrm{bme})}\right]+\hat{\beta}_{12}\left[\mathrm{BME}_{\mathrm{i}(\text { observed })}-\mu_{(\mathrm{bme})}\right]^{2}\right)$.

${ }^{8}$ For presentation convenience, we plot bricks-and-mortar experience up to 28 years in Figure 1. We observe similar diminishing returns to CRM system investments for higher levels of bricksand-mortar experience.
}

TABLE 1

Online Retailers' Strategic Commitments to and Rewards for CRM: Model Results

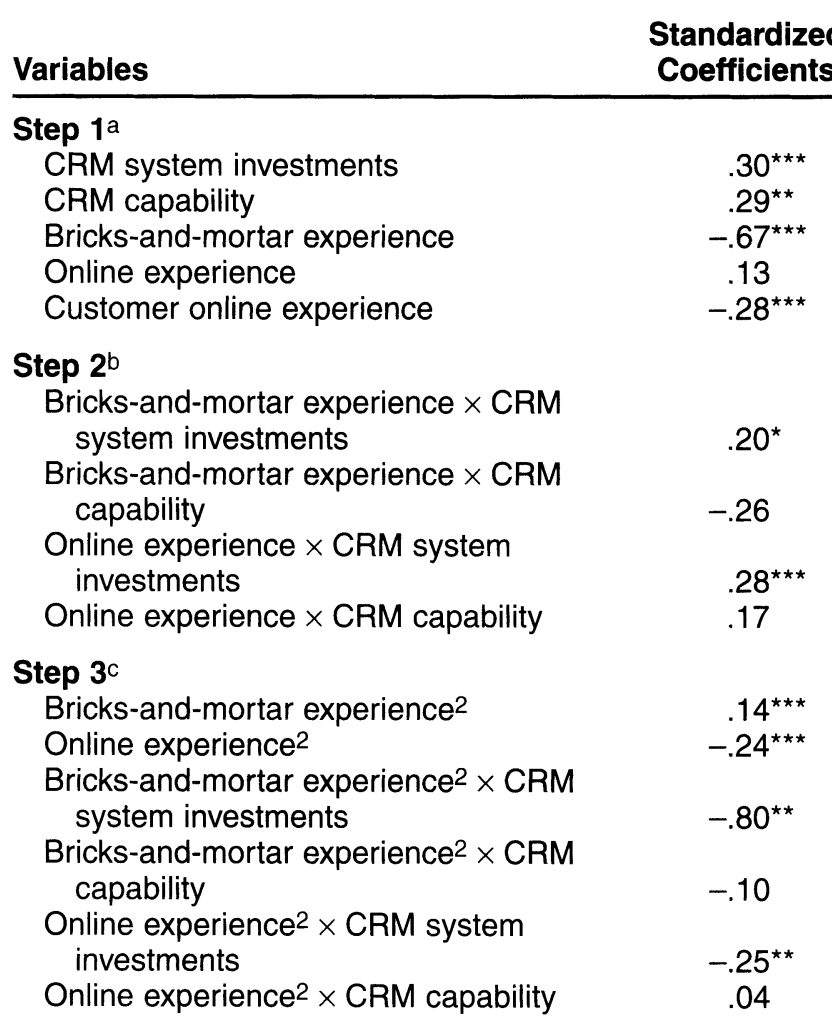

Overall Intercept

$17.43^{\star \star \star}$

Overall $F$ associated with complete model

(degrees of freedom $=15,90$ )

$3.85^{\star \star \star}$

Overall $\mathrm{R}^{2}$ associated with complete model

$.39^{\star \star \star}$

${ }^{*} p<.10$.

${ }^{\star \star} p<.05$.

${ }^{\star * \star} p<.01$.

aThe results from the three-stage model are shown.

bThe change-in- $F$ associated with the introduction of the interaction of the strategic commitment variables (e.g., bricks-and-mortar experience) and with the CRM investment variables is significant (change-in- $\mathrm{F}_{(4,96)}=3.43, p<.01$ ).

cThe change-in- $F$ associated with the introduction of the squared strategic commitment variables (e.g., bricks-and-mortar experience ${ }^{2}$ ) and their interaction with the CRM investment variables is significant (change-in- $\left.F_{(10,90)}=3.76, p<.01\right)$.

below the average return of the firms in our sample (.19) when bricks-and-mortar experience is less than 4 years (.17) and greater than 20 years (.18).$^{9}$ In summary, the significant parameter estimates of the first-order $(b=.20, p<$ $.10)$ and the second-order $(b=-.80, p<.01)$ interaction terms, combined with the inverted U-shaped relationship of the returns on CRM system investments at different levels of bricks-and-mortar experience, support $\mathrm{H}_{1}$.

CRM capability. We next examine the effect of firm bricks-and-mortar experience on the effects of its CRM capability. Notably, both the first-order $\left(\mathrm{BME}_{\mathrm{i}} \times\right.$ CRM_Cap $\left.{ }_{\mathrm{i}}\right)(\mathrm{b}=-.26$, not significant [n.s.] $)$ and secondorder $\left(\mathrm{BME}_{\mathrm{i}}^{2} \times \mathrm{CRM}_{-} \mathrm{Cap}_{\mathrm{i}}\right)(\mathrm{b}=-.10$, n.s. $)$ interactions are

\footnotetext{
${ }^{9}$ The average return level on CRM system investments (unstandardized $b=.19, p<.01$ ) corresponds to the main effect of CRM system investments (standardized $\mathrm{b}=.30, p<.01$ ) in Table 1 .
} 
not significant. Combined with the positive main effect of CRM capability $(\mathrm{b}=.29, p<.05)$, these results suggest that the effect of a firm's CRM capability on customer satisfaction is impervious to its bricks-and-mortar experience.

\section{CRM and Firm Online Experience $\left(\mathrm{H}_{2}\right)$}

CRM system investments. The first-order interaction $\left(\mathrm{OE}_{\mathrm{i}} \times \mathrm{CRM}\right.$ Invest $\left.\mathrm{t}_{\mathrm{j}}\right)$ is positive and significant $(\mathrm{b}=.28$, $p<.01)$, and the second-order interaction $\left(\mathrm{OE}_{\mathrm{i}}^{2} \times\right.$ CRM_Invest $\left.{ }_{\mathrm{i}}\right)$ is negative and significant $(\mathrm{b}=-.25, p<.05)$, in support of $\mathrm{H}_{2}$. We plot the estimated coefficients of CRM system investments at different levels of online experience in Figure 2.

The expected inverted $U$ shape in Figure 2 indicates that moderate online experience strengthens the effects of a firm's CRM system investments more than low and high online experience. Online experience of 4.5 years maximizes customer satisfaction returns on CRM system investments. Additional analysis indicates that CRM returns drop below the average (.19) when online experience is less than

FIGURE 1
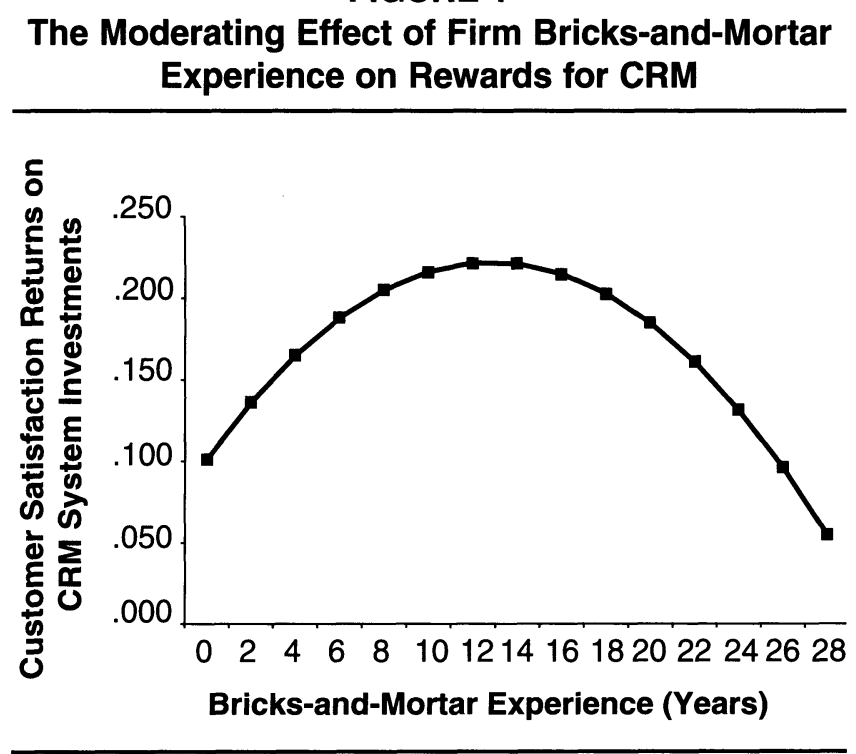

\section{FIGURE 2 \\ The Moderating Effect of Firm Online Experience on Rewards for CRM}

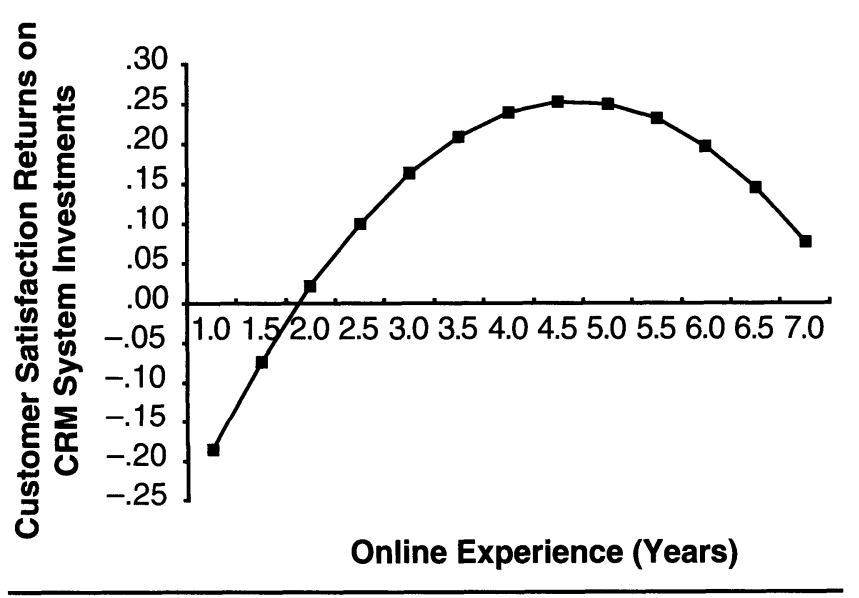

3.0 years (.16) and greater than 6.5 years (.15). Notably, customer satisfaction returns on CRM system investments of very young firms ( $<2$ years) are negative. We conjecture that this may be due to the challenges that confront these nascent firms in the turbulent online retailing market.

In summary, the significant parameter estimates of the first-order $(\mathrm{b}=.28, p<.01)$ and second-order $(\mathrm{b}=-.25, p<$ $.05)$ interaction terms, combined with the inverted U-shaped relationship of the returns on a firm's CRM system investments at different levels of online experience, support $\mathrm{H}_{2}$.

CRM capability. Finally, we examine the effect of a firm's online experience on the effects of its CRM capability. Neither the first-order $\left(\mathrm{OE}_{\mathrm{i}} \times \mathrm{CRM}_{-} \mathrm{Cap}_{\mathrm{i}}\right)(\mathrm{b}=.17$, n.s. $)$ nor the second-order $\left(\mathrm{OE}_{\mathrm{i}}^{2} \times \mathrm{CRM}_{-} \mathrm{Cap}_{\mathrm{i}}\right)(\mathrm{b}=.04$, n.s. $)$ interactions are significant. These results, combined with the positive main effect of CRM capability $(b=.29, p<$ .05 ), suggest that the effect of a firm's CRM capability on customer satisfaction is impervious to its online experience.

\section{Discussion}

\section{CRM System Investments and Firm Strategic Commitments}

The study's findings indicate that firms' prior strategic commitments have impressive effects on the performance of their CRM investments. Specifically, the customer satisfaction effects of CRM system investments are greater for online retailers with moderate levels of bricks-and-mortar experience than for firms with low and high levels of bricks-and-mortar experience. In light of this finding, managers of bricks-and-mortar retailers with moderate bricksand-mortar experience (approximately 12 years) can consider their offline experience an asset. Higher levels of bricks-and-mortar experience ( $>20$ years) produce diminishing customer satisfaction returns on CRM system investments. Perhaps these older incumbent retailers' core rigidities dampen the returns on their CRM system investments in the emerging online market. From an operational perspective, CRM executives can assess the rewards for their firm's and competitors' CRM system investments, given their bricks-and-mortar experience.

With respect to online experience, customer satisfaction effects of online CRM system investments are greater for firms with moderate online experience (approximately 4.5 years) than for firms with low and high online experience. This suggests that there is a window of opportunity in the online retailing market for fast followers to generate greater customer satisfaction returns on their CRM activities than early and later entrants. Finally, managers can use this approach to predict the optimal return on their investment and on their competitors' CRM investments, given online experience levels.

\section{CRM Capability and Firm Strategic Commitments}

Unlike CRM system investments, our findings indicate that a firm's strategic commitments do not moderate the customer satisfaction effects of its CRM capability, which is embodied in its market intelligence acquisition, dissemination, and responsiveness processes. Thus, a firm's market orientation appears to be a robust and effective organizational capability

198 / Journal of Marketing, October 2005 
that operates independently of the two strategic commitments of bricks-and-mortar and online experience. This null result, though not compelling in isolation, is powerful when it is considered in conjunction with the significant moderating effects of CRM system investments.

\section{Limitations and Opportunities for Further Research}

Given the complex relationship between customer satisfaction and other performance metrics (Anderson, Fornell, and Lehmann 1994), the generalizability of this study's findings to other performance metrics is an important issue. Specifically, studies using profit-based performance metrics would provide insight into cost-based effects and revenue-based effects of a firm's CRM investments. In this study, we focused on the role of strategic commitments on CRM returns in online retailing, an important emerging market. Further research that examines this issue in other emerging and mature markets would extend the study's findings in important ways. In addition, researchers could investigate the generalizability of our findings using other strategic commitments, CRM investments, and CRM capabilities.

\section{Conclusion}

In summary, our study makes four contributions. First, we offer a contingent effect of a firm's CRM investments on its performance, shedding some light on the divergent findings between the CRM literature and CRM practice. Second, we offer a strategic vantage point, highlighting the role of two key strategic commitments on the rewards for CRM investments. Third, we provide important insights into CRM activities in online retailing, for which the complex intersection of firm and customer forces shapes firm performance. Fourth, our study offers guidance to practitioners on the contingent nature of rewards for their CRM investments, which should be useful in managing their firms' investments and monitoring their competitors' CRM investments.

\section{Appendix}

Firm Customer Satisfaction $($ mean $=8.68$, s.d. $=.58$, range $=1-10 ; \alpha=.80$ )

How satisfied are you overall with this purchase experience at (merchant name) site? $(1=$ "not at all" to $10=$ "highly")

(Note that the reported mean and standard deviation are across firms, and the alpha is across individuals within firms.)

Firm CRM System Investments (mean $=5.04$, s.d. $=.93$, range $=1-7 ; \alpha=.77$ )

Rate the level of investments your firm makes in the following areas: ( 1 = "low investments," 4 = "moderate investments," and 7 = "high investments")

1. Developing a large installed base of customers

2. Enhancing the performance of our website

3. Providing optimal product pricing

4. Improving the ease of ordering

5. Building a strong attachment to our brands

6 . Enhancing the quality of customer support
Rate your firm relative to industry average. $(1=$ "worse than industry average," 4 = "on par," 7 = better than industry average")

1. CRM acquisition expenses

2. CRM retention expenses

Firm CRM Capability (measured by firm market orientation $)($ mean $=4.92$, s.d. $=.78$, range $=1-7 ; \alpha=.76)$

Rate the extent to which the following statements describe your firm: $(1=$ "strongly agree," 7 = "strongly disagree")

\section{Information generation}

1. In this business, we do and/or buy a lot of market research.

2. We are slow to detect changes in our customers' product preferences.

3. We are slow to detect fundamental shifts in our industry (e.g., competition).

\section{Information dissemination}

1. We have frequent interdepartmental meetings to discuss market trends.

2. Marketing personnel spend time discussing customers' future needs with other departments.

3. Data on customer satisfaction are disseminated at all levels on a regular basis.

4. When one department finds out something important about competitors, it is slow to alert other departments.

\section{Responsiveness}

1. It takes forever to decide how to respond to our competitors' price changes.

2. We tend to ignore changes in our customers' products or service needs.

3. If a major competitor launched an intensive campaign targeting our customers, we would respond immediately.

4. The activities of the different departments are well coordinated.

5. Customer complaints fall on deaf ears in our firm.

6. Even if we came up with a great marketing plan, we probably would not be able to implement it in a timely fashion.

7. When our customers want us to modify a product or service, the departments involved make an effort to do so.

Firm Bricks-and-Mortar Experience (mean $=2161$ days, s.d. $=4432$ days, range $=0-27,393$ days $)$

The difference (in days) between the "days since firm founding" and "days since firm Web entry," both measured from the survey date of May 1, 2001, is the measure of bricks-and-mortar experience.

Firm Online Experience $($ mean $=1180$ days, s.d. $=$ 670 days, range $=1-2497$ days)

The difference (in days) between the days since the industry's first entrant and the days since firm's Web entry. To facilitate interpretation such that larger numbers denote higher online experience, we subtracted the firm's online experience from our survey date of May 1, 2001.

Customer Online Experience $($ mean $=3.19$, s.d. $=$ 1.12 , range $=1-10$ )

The number of online purchases made by the firm's customers in the product category in the previous six months. 


\section{REFERENCES}

Alba, Joseph W., John Lynch, Barton Weitz, Chris Janiszewski, Richard Lutz, Alan Sawyer, and Stacy Wood (1997), "Interactive Home Shopping: Consumer, Retailer, and Manufacturer Incentives to Participate in Electronic Marketplaces," Journal of Marketing, 61 (July), 38-53.

$\rightarrow$ Anderson, Eugene W., Claes Fornell, and Donald R. Lehmann (1994), "Customer Satisfaction, Market Share, and Profitability, Journal of Marketing, 58 (July), 53-66.

$\rightarrow-,-$, and Sanal Mazvancheryl (2004), "Customer Satisfaction and Shareholder Value," Journal of Marketing, 68 (October), 172-85.

Ansari, Asim and Carl F. Mela (2003), "E-Customization," Journal of Marketing Research, 40 (May), 131-45.

Boulding, William, Ajay Kalra, and Richard Staelin (1999), "The Quality Double Whammy," Marketing Science, 18 (4), 463-84

$\rightarrow-,-$, , and Valarie A. Zeithaml (1993), "A Dynamic Process Model of Service Quality: From Expectations to Behavioral Intentions," Journal of Marketing Research, 30 (February), 7-27.

$\rightarrow$ Chandy, Rajesh K. and Gerard J. Tellis (2000), "The Incumbent's Curse? Incumbency, Size, and Radical Product Innovation," Journal of Marketing, 64 (July), 1-17.

Day, George S. and C. Van den Bulte (2002), "Superiority in Customer Relationship Management: Consequences for Competitive Advantage and Performance," working paper, Wharton School of Business, University of Pennsylvania.

Degeratu, Alexandru, Arvind Rangaswamy, and Jianan Wu (2000), "Consumer Choice Behavior in Online and Traditional Supermarkets: The Effects of Brand Name, Price, and Other Search Attributes," International Journal of Research in Marketing, 17 (March), 55-79.

Dignan, Larry (2002), “CRM: Dream or Nightmare?" (accessed April 3, 2002), [available at http://www.cnetnews.com].

Fornell, Claes (1992), "A National Customer Satisfaction Barometer: The Swedish Experience," Journal of Marketing, 56 (January), 6-21.

Gartner Group (2003), "CRM Success Is in Strategy and Implementation, Not in Software," (accessed December 2003), [available at http://www.gartner.com].

$\rightarrow$ Geyskens, Inge, Katrijn Gielens, and Marnik G. Dekimpe (2002), "The Market Valuation of Internet Channel Additions," Journal of Marketing, 66 (April), 102-119.

Ghosh, Shikhar (1998), "To Assess the Risks and Opportunities, You Need to Know What's Possible," Harvard Business Review, 76 (March-April), 126-35.

$\rightarrow$ Golder, Peter N. and Gerard J. Tellis (1993), "Pioneer Advantage: Marketing Logic or Marketing Legend?" Journal of Marketing Research, 30 (May), 158-70.

Gupta, Sunil, Donald R. Lehmann, and Jennifer Ames Stuart (2004), "Valuing Customers," Journal of Marketing Research, 40 (February), 7-18.

$\rightarrow$ Homburg, Christian and Christian Pflesser (2000), "A MultipleLayer Model of Market-Oriented Organizational Culture: Measurement Issues and Performance Outcomes," Journal of Marketing Research, 37 (November), 449-62.

Infoworld (2001), "CRM Tabbed as Top Retail Initiative for 2001," (accessed December 10, 2003), [available at http://www. infoworld.com].

Irwin, Julie R. and Gary H. McClelland (2001), "Misleading Heuristics and Moderated Multiple Regression Models," Journal of Marketing Research, 38 (February), 100-109.

$\rightarrow$ Jayachandran, Satish, Subhash Sharma, Peter Kaufman, and Pushkala Raman (2005), "The Role of Relational Information Processes and Technology Use in Customer Relationship Management," Journal of Marketing, 69 (October), 177-92.
Johnson, Eric J., Steven Bellman, and Gerald L. Lohse (2003), "Cognitive Lock-In and the Power Law of Practice," Journal of Marketing, 67 (April), 62-75.

Kanter, Rosabeth Moss (2001), "The Ten Deadly Mistakes of Wanna-Dots," Harvard Business Review, 79 (January), 91-100.

Kohli, Ajay K. and Bernard J. Jaworski (1990), "Market Orientation: The Construct, Research Propositions, and Managerial Implications," Journal of Marketing, 54 (April), 1-18.

- $\longrightarrow$, and Ajith Kumar (1993), "MARKOR: A Measure of Market Orientation," Journal of Marketing Research, 30 (November), 467-77.

Lynch, John G., Jr., and Dan Ariely (2000), "Wine Online: Search Costs Affect Competition on Price, Quality, and Distribution," Marketing Science, 19 (1), 83-103.

$\rightarrow$ Mason, Charlotte H. and William D. Perreault (1991), "Collinearity, Power, and Interpretation of Multiple Regression Analysis," Journal of Marketing Research, 28 (August), 268-80.

$\rightarrow$ Mithas, Sunil, M.S. Krishnan, and Claes Fornell (2005), "Why Do Customer Relationship Management Applications Affect Customer Satisfaction?" Journal of Marketing, 69 (October), 201-209.

Nelson, Richard and Sidney G. Winter (1982), An Evolutionary Theory of Economic Change. Cambridge, MA: Belknap Press.

Reibstein, David J. (2002), "What Attracts Customers to Online Stores, and What Keeps Them Coming Back?" Journal of the Academy of Marketing Science, 30 (Fall), 465-73.

Reinartz, Weiner, Manfred Krafft, and Wayne D. Hoyer (2004), "The CRM Process: Its Measurement and Impact on Performance," Journal of Marketing Research, 41 (August), 293-305.

and V. Kumar (2000), "On the Profitability of Long-Life Customers in a Noncontractual Setting: An Empirical Investigation and Implications for Marketing," Journal of Marketing, 64 (October), 17-35.

$\rightarrow-$ and - (2003), "The Impact of Customer Relationship Characteristics on Profitable Lifetime Duration," Journal of Marketing, 67 (January), 77-99.

$\rightarrow \longrightarrow$, Jacqueline Thomas, and V. Kumar (2005), "Balancing Customer Acquisition and Retention Resources to Maximize Customer Profitability," Journal of Marketing, 69 (January), 63-79.

Rogers, Everett M. (1995), Diffusion of Innovations. New York: The Free Press.

Rust, Roland T., Katherine C. Lemon, and Valarie Zeithaml (2004), "Return on Marketing: Using Customer Equity to Focus Marketing Strategy," Journal of Marketing, 68 (January), 109-127.

and Peter C. Verhoef (2005), "Optimizing the Marketing Interventions Mix in Intermediate-Term CRM," Marketing Science, 24, forthcoming.

Srivastava, Rajendra K., Tasadduq Shervani, and Liam Fahey (1998), "Market-Based Assets and Shareholder Value: A Framework for Analysis," Journal of Marketing, 62 (January), 2-18.

$\rightarrow$ Szulanski, Gabriel (1996), "Exploring Internal Stickiness: Impediments to the Transfer of Best Practices Within the Firm," Strategic Management Journal, 17 (1), 27-43.

Venkatesan, Rajkumar and V. Kumar (2004), "A Customer Lifetime Value Framework for Customer Selection and Resource Allocation Strategy," Journal of Marketing, 68 (October), 106-125.

Wind, Jerry and Vijay Mahajan (2002), Convergence Marketing: Strategies for Reaching the New Hybrid Consumer. Harlow, UK: Prentice Hall.

Zauberman, Gal (2003), "The Intertemporal Dynamics of Consumer Lock-In," Journal of Consumer Research, 30 (December), 405-419. 